International Journal of Current Advanced Research

ISSN: O: 2319-6475, ISSN: P: 2319 - 6505, Impact Factor: SJIF: 5.995

Available Online at www.journalijcar.org

Volume 6; Issue 3; March 2017; Page No. 2649-2651

DOI: http://dx.doi.org/10.24327/ijcar.2017.2651.0065

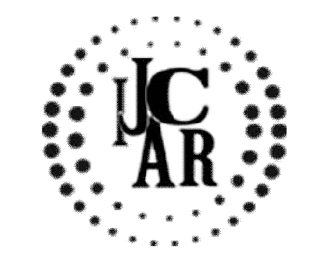

Research Article

\title{
DOES FAMILY HISTORY OF HYPERTENSION IN FIRST YEAR MBBS STUDENTS INFLUENCE KNOWLEDGE REGARDING DIAGNOSIS AND MANAGEMENT OF HYPERTENSION?
}

\author{
Ramaprabha $\mathbf{P}^{1 *}$., Dhandapany Senthil Pragash ${ }^{2}$ and Aravindkumar $\mathbf{R}^{3}$
}

${ }^{1}$ Department of Physiology, DM WIMS Medical College, Wayanad, Kerala. 673577

2Department of Microbiology, Melmaruvathur Adhiparasakthi Institute of Medical Sciences and Research, Melmaruvathur, Tamilnadu - 603319.

${ }^{3}$ Department of Physiology, Rajah Muthiah Medical College, Annamalai University, Annamalai Nagar, Tamil Nadu 608002

A R T I C L E I N F O

\section{Article History:}

Received $18^{\text {th }}$ December, 2016

Received in revised form $16^{\text {th }}$ January, 2017

Accepted $26^{\text {th }}$ February, 2017

Published online $28^{\text {th }}$ March, 2017

\section{Key words:}

Hypertension, First-year MBBS, Knowledge, Family history

\begin{abstract}
A B S T R A C T
Background: Hypertension is one of the major metabolic risk factors for cardiovascular disease, and accounts for substantial mortality. There are very few studies investigating the knowledge of MBBS students regarding hypertension. In this study, we explored the relationship between presence of family history of hypertension and knowledge regarding diagnosis, management and complications of hypertension in first year MBBS students.

Methods: This study was conducted in a private medical college in Tamil Nadu, India. 149 first year MBBS students were recruited in this cross-sectional study. Approval was obtained from the Institutional Ethics Committee, and a pre-tested, structured questionnaire was administered to all respondents.

Results: Most students knew the basics of hypertension- what it was, and how it was diagnosed. Only $42 \%$ of those without family history of hypertension knew that treatment is lifelong, as compared to $65 \%$ of those with family history $(p=0.005) .92 .5 \%$ of those with positive family history knew that salt-restricted diet is part of management, in contrast to $76.8 \%$ of those without positive family history.

Conclusions: Those with family history of hypertension had significantly better knowledge about the duration of treatment. Similarly, those with a positive family history were significantly more likely to know that salt-restricted diet is advised as part of management of hypertension.
\end{abstract}

Copyright $@ 2017$ Ramaprabha $\boldsymbol{P}$ et al. This is an open access article distributed under the Creative Commons Attribution License, which permits unrestricted use, distribution, and reproduction in any medium, provided the original work is properly cited.

\section{INTRODUCTION}

Globally, hypertension is responsible for nearly $1 / 3^{\text {rd }}$ of the 17 million annual deaths due to cardiovascular disease (World Health Organization, 2013). It is responsible for $51 \%$ of stroke deaths and at least $45 \%$ of deaths due to heart disease, and disproportionately affects people in low and middleincome countries (WHO South-East Asia Region Office, 2013b; World Health Organization, 2013, 2016a). This is on account of weak health systems, greater populations, and large number of undiagnosed, untreated and uncontrolled patients in these countries (World Health Organization, 2013). The prevalence of hypertension is on the rise, with $40 \%$ of the world's adults over 25 years age having hypertension (World Health Organization, 2013, 2016b). It is a major public health problem(WHO South-East Asia Region Office, 2013a), and was the World Health Day theme in 2013(WHO South-East Asia Region Office, 2013b).

\footnotetext{
*Corresponding author: Ramaprabha $\mathbf{P}$

Department of Physiology, DM WIMS Medical College,

Wayanad, Kerala. 673577
}

There is a paucity of literature regarding medical students' knowledge about hypertension (Rehman et al., 1994; Shaikh et al., 2011). This study was conducted in a private medical college in south India to determine if family history of hypertension influences awareness of hypertension in first year MBBS students.

\section{MATERIALS AND METHODS}

This study was conducted among first year MBBS students of Melmaruvathur Adhiparasakthi Institute of Medical Sciences and Research, a private medical college in Tamil Nadu, India. The institution has been awarded 150 seats for the MBBS course.We decided to include all 150 students in this crosssectional study.

The study was conducted after the end of Semester 1, in February 2014, and was limited to first year MBBS students.Students had not been formally taught about hypertension at the time of study.

Before conducting the study, we obtained approval from the Institutional Ethics Committee as well as written informed 
consent from all students. All but one student participated in the study.A pre-tested, structured questionnaire containing questions regarding diagnosis, management, complications and prevention of hypertension was administered to study subjects.

Data entry and transformation were performed using Microsoft Office Excel 2010. Data analyses were performed using EZR (version 1.34 (R Commander version 2.30))(Kanda, 2013). Descriptive statistics, and chi-square test were performed. A $p$ value of $\leq 0.05$ was considered statistically significant.

\section{RESULTS}

There were a total of 149 respondents, of whom $75(50.3 \%)$ were male, and 74(49.6\%) were female.

Students were asked to indicate their place of residence, and if there was a family history of hypertension. 80 students indicated that they had a family history of hypertension, while 69 reported no such family history. Of those with family history of hypertension, $56(70 \%)$ and $24(30 \%)$ resided in urban and rural areas respectively. In contrast, of those without family history of hypertension, 38 (55.1\%) and 31 $(44.9 \%)$ were from urban and rural areas respectively.

The results of chi-square test are presented in table.
From table, it is seen that most students correctly answered the question 'what is hypertension?'. However, a greater proportion of those without family history of hypertension correctly answered the question asking what the purpose of anti-hypertension treatment is. A similar pattern was noticed with respect to the question asking 'How is hypertension diagnosed?'.

Greater proportions of students with family history of hypertension gave correct answers to questions regarding hypertensive heart disease and hypertensive renal disease, and medicines to manage the condition. However, these differences did not attain statistical significance. $52(65 \%)$ of those with a family history of hypertension mentioned that the duration of treatment was lifelong. In comparison, only 29 $(42 \%)$ of those without family history of hypertension gave the correct answer. This difference was statistically significant, with $\mathrm{p}$ value 0.005 .

Awareness regarding avoidance of salt, pickle; reducing body weight; and alcohol cessation was similar between those with family history of hypertension, and those without such history. $74(92.5 \%)$ of those with positive family history correctly mentioned salt restricted diet as a means of managing hypertension. In contrast, only 53 (76.8\%) of those with negative family history gave the correct answer.

Table Student responses to questions, disaggregated by presence or absence of family history

\begin{tabular}{|c|c|c|c|c|}
\hline Item & Response & $\begin{array}{c}\text { Family history present } \\
\text { n(\%) }\end{array}$ & $\begin{array}{c}\text { Family history absent } \\
\text { n(\%) }\end{array}$ & p value \\
\hline \multirow{2}{*}{ What is hypertension? } & Increase in BP & $79(98.8)$ & $68(98.6)$ & \multirow{2}{*}{1} \\
\hline & Others & $1(1.2)$ & $1(1.4)$ & \\
\hline \multirow{3}{*}{$\begin{array}{l}\text { Anti-hypertension treatment } \\
\text { is to control }\end{array}$} & Blood Pressure & $72(90)$ & $67(97.1)$ & \multirow{2}{*}{0.10} \\
\hline & Others & $8(10)$ & $2(2.9)$ & \\
\hline & \multicolumn{4}{|c|}{ Diagnosis of hypertension and its complications } \\
\hline \multirow{2}{*}{ Hypertension is detected } & By regular BP monitoring & $76(95)$ & $68(98.6)$ & \multirow{2}{*}{0.37} \\
\hline & Others & $4(5)$ & $1(1.4)$ & \\
\hline \multirow{2}{*}{$\begin{array}{c}\text { Features of Hypertensive } \\
\text { heart disease are }\end{array}$} & $\begin{array}{c}\text { Tachycardia, chest pain, pedal } \\
\text { oedema }\end{array}$ & $75(93.8)$ & $62(89.9)$ & \multirow{2}{*}{0.54} \\
\hline & $\begin{array}{l}\text { oedema } \\
\text { Others }\end{array}$ & $5(6.2)$ & $7(10.1)$ & \\
\hline \multirow{2}{*}{$\begin{array}{l}\text { Features of hypertensive } \\
\text { renal disease are }\end{array}$} & Oliguria, facial oedema & $41(51.2)$ & $34(49.3)$ & \multirow{2}{*}{0.87} \\
\hline & Others & $39(48.8)$ & $35(50.7)$ & \\
\hline \multicolumn{5}{|c|}{ Management of hypertension } \\
\hline \multirow{2}{*}{ Medicines } & Yes & $77(96.2)$ & $60(87)$ & \multirow{2}{*}{0.06} \\
\hline & No/ Don't know & $3(3.8)$ & $9(13)$ & \\
\hline \multirow{2}{*}{ Meditation } & Yes & $78(97.5)$ & $68(98.6)$ & \multirow{2}{*}{1} \\
\hline & No/ Don't know & $2(2.5)$ & $1(1.4)$ & \\
\hline \multirow{2}{*}{ Exercise } & Yes & $69(86.2)$ & $63(91.3)$ & \multirow{2}{*}{0.4} \\
\hline & No/ Don't know & $11(13.8)$ & $6(8.7)$ & \\
\hline \multirow{2}{*}{ Duration of treatment is } & Lifelong & $52(65)$ & $29(42)$ & \multirow{2}{*}{0.005} \\
\hline & Others & $28(35)$ & $40(58)$ & \\
\hline \multirow{2}{*}{ After normalization of BP } & Decrease/ continue same dose & $72(90)$ & $61(88.4)$ & \multirow{2}{*}{0.79} \\
\hline & Others & $8(10)$ & $8(11.6)$ & \\
\hline \multirow{2}{*}{$\mathrm{No} /$ stop smoking } & Yes & $59(73.8)$ & $57(82.6)$ & \multirow{2}{*}{0.23} \\
\hline & No/ Don't know & $21(26.2)$ & $12(17.4)$ & \\
\hline \multirow{2}{*}{ Not/stop consume alcohol } & Yes & $61(76.2)$ & $53(76.8)$ & \multirow{2}{*}{1} \\
\hline & No/ Don't know & $19(23.8)$ & $16(23.2)$ & \\
\hline \multirow{2}{*}{ Salt Restricted Diet } & Yes & $74(92.5)$ & $53(76.8)$ & 001 \\
\hline & No/ Don't know & $6(7.5)$ & $16(23.2)$ & 0.01 \\
\hline Hypertensive patients should & Salt, pickle & $76(95)$ & $66(95.7)$ & \\
\hline avoid & Others & $4(5)$ & $3(4.3)$ & 1 \\
\hline Reducing hody weioht & Decreases BP & $24(30)$ & $21(30.4)$ & 1 \\
\hline Reducing body weight & Others & $56(70)$ & $48(69.6)$ & 1 \\
\hline & Con & lications & & \\
\hline Complications of & Heart failure, stroke, renal disease & $76(95)$ & $66(95.7)$ & 1 \\
\hline hypertension are & Others & $4(5)$ & $3(4.3)$ & 1 \\
\hline & Reduce body weight; avoid & & & \\
\hline $\begin{array}{l}\text { How can patients prevent } \\
\text { complications? }\end{array}$ & $\begin{array}{l}\text { smoking, alcohol; dietary } \\
\text { management }\end{array}$ & $70(87.5)$ & $57(82.6)$ & 0.48 \\
\hline & Others & $10(12.5)$ & $12(17.4)$ & \\
\hline
\end{tabular}


This difference was statistically significant, with a $p$ value of 0.01 .

\section{DISCUSSION}

Hypertension is one of the major metabolic risk factors for the development of cardiovascular diseases (World Health Organization, 2013, 2016).

However, a large proportion of those with the condition are unaware of their status, and risk the development of cardiovascular diseases, as well as premature mortality (World Health Organization, 2013).

This study's results revealed that first year students have some knowledge about hypertension even before they are formally taught about it. This is similar to the findings reported by some other investigators (Rehman et al., 1994; Shaikh et al., 2011).

Despite this, there are some major gaps in knowledge regarding management of hypertension. The most prominent is information that treatment is lifelong. This is on account of the fact that failure to continue treatment is likely to result in catastrophic health care expenses due to cardiovascular diseases like stroke (World Health Organization, 2013). While those with family history of hypertension knew that treatment was lifelong, those without such history did not. Considering that a large proportion of those with hypertension are unaware of their condition, the proportion of people with hypertension who are aware of their condition is relatively small.

The other major gap in respondents' knowledge is regarding the advice to follow a salt restricted diet. Although a large proportion of those with positive family history knew about this, the same was not true for those without a family history of hypertension.

Salt control is a major aspect of disease control in hypertension, and is advocated at both the individual and population level (World Health Organization, 2014). Since knowledge influences practice, it is imperative that awareness regarding the benefits of a low salt diet is increased.

This study is one of few that have assessed the knowledge level of first year MBBS students regarding hypertension, and is unique in evaluating the influence of family history on this knowledge.

Since there are no other known studies on this topic, it is not possible to compare our findings with those of other investigators. This lack of external comparison is both a strength and limitation of this study.

\section{CONCLUSIONS}

Although the knowledge of first year MBBS students regarding the diagnosis and management of hypertensionis acceptable on the whole, there are critical gaps in their knowledge.

Those with a family history of hypertension are significantly more likely to know that treatment for hypertension is lifelong, and that following a salt-restricted diet is a part of management.
We recommend that more such studies are conducted, and the findings of this study corroborated.

\section{Acknowledgements}

We would like to thank the students who participated in this study.

We also wish to thank Dr. Liaquat Roopesh Johnson for providing technical inputs during the preparation of this article.

\section{References}

Kanda, Y. (2013). Investigation of the freely available easyto-use software "EZR" for medical statistics. Bone Marrow Transplantation, 48(October 2012), 452- 458. https://doi.org/10.1038/bmt.2012.244

Rehman, A., Rehman, T., Shaikh, M. A., Naqvi, S. A. A., Anwar, S., \& Naqvi, A. (1994). Students ' Corner Original Article Awareness of hypertension among the medical students and junior doctors - a multicenter study from Pakistan. Journal of Pakistan Medical Association, 61(11), 1153-1157. Retrieved from http://jpma.org.pk/PdfDownload/3128.pdf

Shaikh, R. B., Mathew, E., Sreedharan, J., Muttappallymyalil, J., Sharbatti, S. Al, \& Basha, S. a. (2011). Knowledge regarding risk factors of hypertension among entry year students of a medical university. Journal of Family and Community Medicine, 18(3), 124-9. https://doi.org/10.4103/22308229.90011

WHO South-East Asia Region Office. (2013a). HIGH BLOOD PRESSURE A Public Health Priority. New Delhi. Retrieved from http://www.searo.who.int/ entity/world_health_day/leaflet_public_health_priority hbp_ncd_whd_2013_factbuffet.pdf?ua $=1$

WHO South-East Asia Region Office. (2013b). World Health Organization, World Health Day - 7 April 2013. Retrieved April 2, 2017, from http://www.searo. who.int/entity/world_health_day/en/

World Health Organization. (2013). A global brief on Hypertension: Silent killer, global public health crisis. Geneva. Retrieved from www.who.int/about/licensing/ copyright_form/en/index.html

World Health Organization. (2014). Guideline: Sodium intake for adults and children Sodium intake for adults and children. Geneva. Retrieved from http://apps. who.int/iris/bitstream/10665/77985/1/9789241504836_ eng.pdf?ua $=1 \& u a=1$

World Health Organization. (2016). Fact sheet: Cardiovascular diseases (CVDs). WHO. World Health Organization. Retrieved from http://who.int/medi acentre/factsheets/fs317/en/

World Health Organization. (2016). WHO | World Health Organization. Retrieved April 2, 2017, from http://gamapserver.who.int/gho/interactive_charts/ncd/ mortality/cvd/atlas.html

World Health Organization. (2016). WHO | World Health Organization. Retrieved April 2, 2017, from http://gamapserver.who.int/gho/interactive_charts/ncd/r isk_factors/blood_pressure_prevalence/atlas.html 